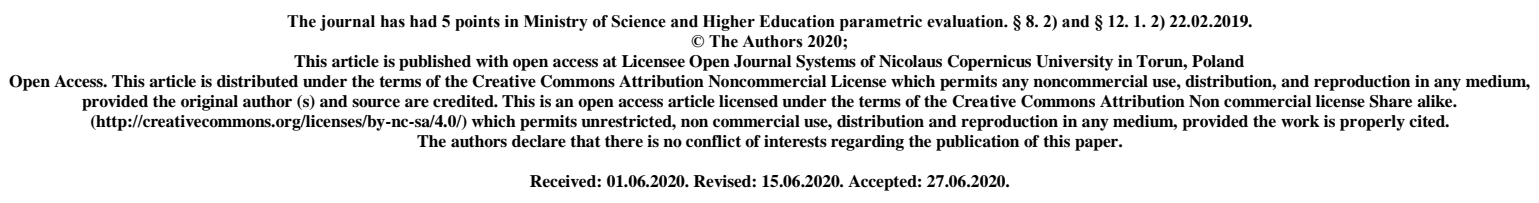

\title{
The use of interferon in medicine
}

\author{
Waldemar Pluta, Wioleta Dudzińska, Anna Lubkowska ${ }^{1}$
}

${ }^{1}$ Department of Functional Diagnostics and Physical Medicine, Pomeranian Medical University in Szczecin, Żołnierska 54 Str., 71-210 Szczecin, Poland

\begin{abstract}
Interferons are low-molecular weight glycoproteins. They are characterized by paracrine and autocrine activity. Their production and release occurs through various types of cells, which ultimately leads to the protection of the body against viral infections. Interferons do not have direct antiviral activity but affect cells, inducing the formation of antiviral agents and "antiviral readiness" in them. Thanks to their properties interferons have been widely used in the treatment of many diseases, among others hepatitis B, hepatitis $\mathrm{C}$ and multiple sclerosis. In addition, they show anti-cancer effects, even in the case of chronic myeloid leukemia. They are currently an important element in the search for a drug against SARS-CoV-2.
\end{abstract}

KEY WORDS: interferon; hepatitis C; COVID19 
Interferons were discovered in 1957 by Alick Isaacs and Jean Lindenmann, who, by analyzing the phenomenon of viral interference, showed the presence of proteins that protect cells from infection [1]. The name of these cytokines comes from the ability to impede - interference virus replication [2].

Interferons are low-molecular weight glycoproteins that are synthesized by mammals, reptiles, fish and birds. They consist of 143-146 amino acid residues [3]. Their production and release occurs through various types of cells, which ultimately leads to the protection of the body against viral infections.

Currently, three types of interferons are known: IFN type I, type II and type III. The classification is based on the nucleotide sequence, interaction with specific receptors, chromosomal location, structure and physicochemical properties. Within type I there are: IFN- $\alpha, \beta, \delta, \varepsilon, \zeta, \kappa, v, \tau, \omega$; type II: IFN- $\gamma$; type III: IFN- $\lambda 1, \lambda 2, \lambda 3$ [4].

The aim of this study was to evaluate the use of interferon in the treatment. Our study material consisted of publications, which were found in PubMed, ResearchGate and Google Scholar databases. In order to find the proper publications, the search has been conducted with the use of a combination of key words like: "interferon", "COVID19", "SARS-CoV-2", "hepatitis B", "hepatitis C". The first step was to find proper publications from the last 10 years. The second step was to carry out an overview of the found publications.

Table 1. Characteristics of interferons [5]

\begin{tabular}{|l|l|l|l|}
\hline & IFN- $\boldsymbol{\alpha}$ & IFN- $\boldsymbol{\beta}$ & IFN- $\boldsymbol{\gamma}$ \\
\hline Name (former) & $\begin{array}{l}\text { Leukocytic } \\
\text { lymphocytic }\end{array}$ & Fibrocystic & Immunological \\
\hline Type & I & I & II \\
\hline Main source & Plasmats, dendritic cells & Fibroblasts & $\begin{array}{l}\text { Lymphocytes, T, NK, } \\
\text { NKT }\end{array}$ \\
\hline Induction factors & Viruses, poly I: C & Viruses, poly I: C & Antigens, mitogens \\
\hline Number of coding genes & $>13$ & 1 & 1 \\
\hline Number of introns of & 0 & 0 & 3 \\
\hline $\begin{array}{l}\text { Location } \\
\text { chromosomes }\end{array}$ & 9 & 9 & 12 \\
\hline $\begin{array}{l}\text { Number of amino acid } \\
\text { residues }\end{array}$ & $165-166$ & 166 & 146 \\
\hline \begin{tabular}{l} 
Glycosylation \\
\hline
\end{tabular} & No & Yes & Yes \\
\hline
\end{tabular}

\section{DESCRIPTION OF THE STATE OF KNOWLEDGE}

\section{Activity of interferons}

The activity of interferons is the result of a chain reaction that involves the reversible association of IFN with their specific receptors located on the surface of cells [6].

Interferons are characterized by paracrine and autocrine activity. They perform immunomodulatory functions, participate in the regulation of intercellular interactions, modulate intracellular pathways, increase the efficiency of specific and non-specific response 
mechanisms, are involved in the anti-tumor response and play a key role in the immune response in viral infections $[7,8]$.

Interferons do not have direct antiviral activity but affect cells, inducing the formation of antiviral agents and "antiviral readiness" in them. Obtaining this effect is possible by only 50 IFN molecules, which act on a cell, and this state can be maintained in it for a few days. Interferons activate a number of enzymes in the cell that allow the degradation of viral genetic material, causing the so-called antiviral status [3]. By binding to specific receptors on the surface of cells, they trigger signaling cascades that induce antiviral defense mechanisms. As a result of the protective activity of interferon the binding of virus to cells and the penetration of virus particles into them are stopped and the release of the nucleocapsid of the casing is inhibited.

The transcription and translation of structural proteins that prevent virions or budding of viruses is impaired. As a result of the degradation of viral mRNA, inhibition of the synthesis of viral protein chains is activated, which in turn leads to stimulation of immune cells [4]. Antitumor activity results, among others, from strong stimulation of the synthesis of antigens characteristic of the tumor and present in its cells, thanks to which they are better recognizable and sensitive to attack of immune mechanisms [3].

One of the roles of interferons is the stimulation of the synthesis of oligoisoadenylate synthase. These cytokines increase the activity of these enzymes about 50-100 times. The presence of double-stranded RNA induces the formation of adenylate oligonucleotides, up to 15 nucleotides in length, which are connected by 2 ', 5' phosphodiester bonds. These oligonucleotides activate the endoribonuclease -RNase L, which, by breaking down viral mRNAs, can block the viral life cycle.

An important enzyme activated by IFN is protein kinase R, whose activity under the influence of IFN increases 20-fold. This kinase, undergoes autophosphorylation and phosphorylates the protein synthesis initiating factor (eIF-2 $\alpha$ ), which is most important for its action, and also phosphorylates several other cellular proteins. As a result, the translation and synthesis of viral proteins are inhibited.

The activation of the Mx gene is another important anti-viral mechanism induced by IFN- $\alpha$ and IFN- $\beta$. This gene produces GTPase, which has the ability to block the transport of viral ribonucleins, which ultimately leads to drastic inhibition of influenza virus replication of some other RNA viruses.

The beneficial effects of interferons are also due to their ability to activate the expression of several adenosine deaminase isoforms, which in turn deaminate adenosine within doublestranded RNA. As a result of this RNA editing, inosines are formed instead of adenosines, and the stability of viral RNA decreases.

An ability that only Type I interferons exhibit is the induction of p53 protein expression called the "genome guardian". 


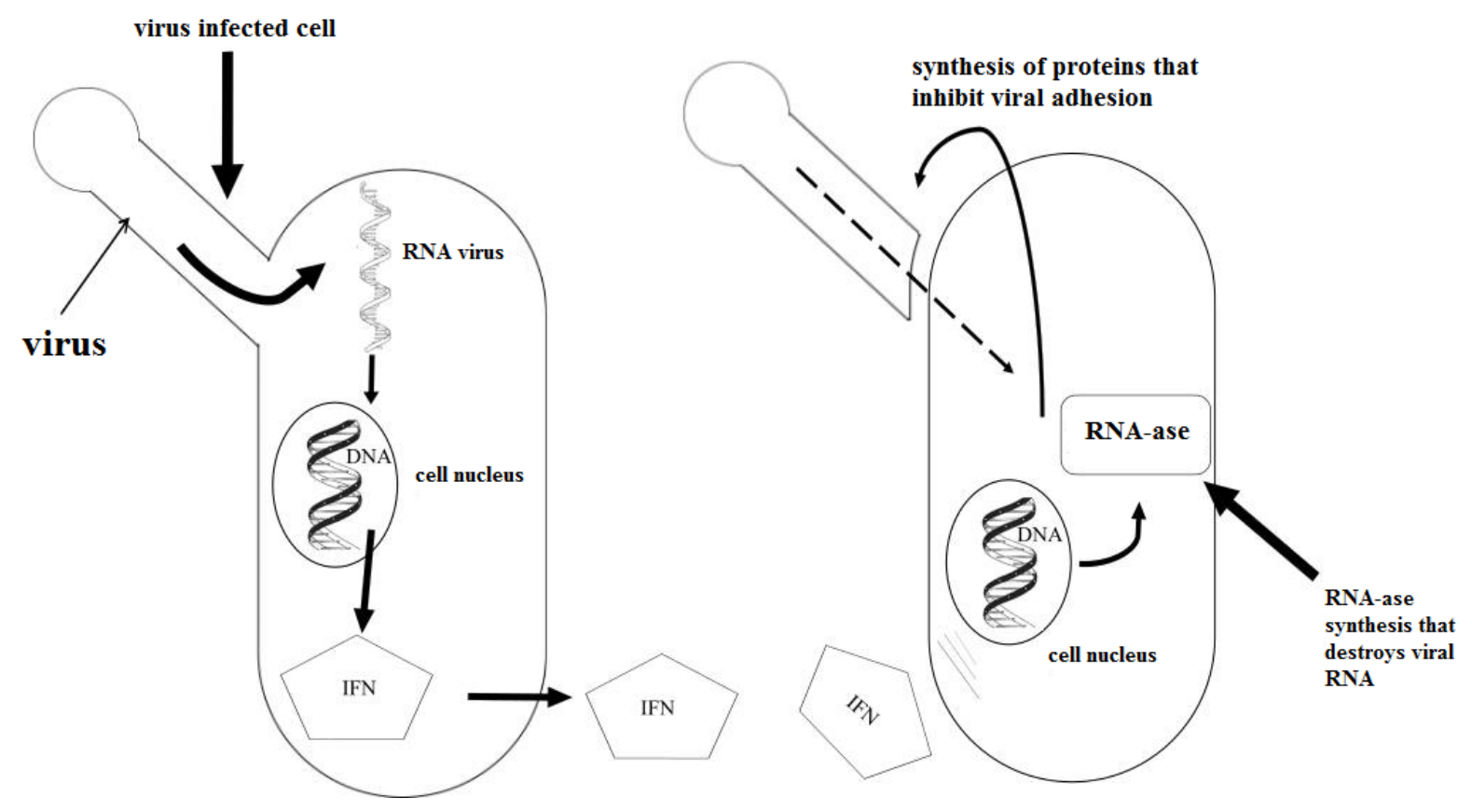

Figure 1. Antiviral effect of interferon [9].

Interferons affect the immune system by increasing the expression of certain molecules and surface receptors (e.g. CD80, FcR), activating macrophages and enhancing phagocytosis, enhancing the expression of MHC molecules, enhancing the cytotoxicity of NK cells, Tc lymphocytes, and $\mathrm{K}$ cells, inducing the production of other cytokines (e.g. IL-1, IL-6, CCL10 / IP10, CCL9 / MIG, TNF- $\alpha$ ). Interferons also act as an activator of NK cell and macrophage cytotoxicity and potentiate the cytotoxic effect of TNF- $\alpha$.

\section{The use of recombinant IFN in medicine}

The properties of $\alpha$ interferons are used in therapy for many diseases, including cancer therapies [7]. Receiving interferon genetic engineering made it possible to use them in therapy. These proteins have been shown to work in many different types of cancers, both solid tumors and proliferative hematological processes. Interferons are being used alone, in combination with cytostatic and other immunotherapy methods.

The first use of cytokines in therapy dates back to the seventies, when they were used to treat bone sarcomas in children. Natural IFN was used in the therapy. The results showed a beneficial effect, however, due to the lack of a control group, it was impossible to draw objective conclusions of this treatment [10].

\section{Hepatitis C}

Interferon $\alpha$ monotherapy was not recognized as a standard strategy in the treatment of hepatitis C until 1991 [11]. The recommended standard of treatment was INF- $\alpha$ therapy at a dose of 3 million units injected 3 times a week, and the entire therapy lasted for 48 weeks [12]. The results showed that sustained virological response (SVR) is possible in less than $20 \%$ of patients treated $[13,14]$.

The change in the standard strategy for treating hepatitis $\mathrm{C}$ was made because of studies by Brillanti et al. [15]. 20 patients in whom interferon $\alpha$ treatment had no effect participated in 
the study. The subjects were divided into two groups in which different treatments were used. The first group was subjected to interferon monotherapy, while the second group received oral ribavirin in addition to interferon. SVR at $40 \%$ was noted in the group with modified INF therapy. Further studies have shown that the addition of ribavirin to IFN therapy increases SVR levels from below $20 \%$ to $40 \%$.

In contrast to $\mathrm{HBV}$, it is not possible to carry out preventive specific therapy in the form of active (vaccine) or passive (antibody) immunization, unlike HBV. The lack of a suitable vaccine results from the fact that a large genetic variable virus [16].

Potential patients eligible for IFN and combination therapy may be patients who meet the following criteria:

- $\quad$ HCV-RNA in serum,

- $\quad$ constantly (possibly - periodically) increased ALT activity (> $100 \mathrm{IU})$,

- $\quad$ inflammatory changes in the liver biopoint

- $\quad$ age 65 is considered borderline

Limitations in IFN therapy should be analyzed in detail. First of all, pregnant women, drug addicts and alcoholics cannot be treated with IFN until the pregnancy is over or they are over the addiction. Absolute contraindications are: significant cytopenia, kidney transplantation, severe depression, autoimmune diseases and hyperthyroidism, while relative contraindications are diabetes, hypertension, neurological and psychiatric disorders, and clinical signs of heart disease (coronary artery disease) or kidney disease.

The final response to IFN and combination therapies is assessed according to biochemical criteria: normalization of A1AT and / or virological activity: HCV-RNA loss in serum [7].

In patients treated with INF- $\alpha$ therapy, at least one adverse effect is detected in $90 \%$ of cases. Premature termination of therapy occurs in $2-10 \%$ of patients. Dose reduction is used in $15 \%$ of patients, while therapy is discontinued in 5\% [17].

The most information on the occurrence of life-threatening symptoms is provided by Italian multicentre retrospective studies on a group of 11241 patients. Five patients $(0.04 \%)$ died during the study, including one due to multiple organ failure and four due to liver failure. Undesirable life-threatening symptoms were found in 8 patients (0.07\%), including: granulocytopenia below $500 / \mathrm{mm} 3$ in 1 person, thrombobocytopenia below 25,000/ mm 3 in 5 , and depression with suicide attempt in 2 persons [18].

Among patients undergoing IFN- $\alpha$ therapy, over $50 \%$ need psychiatric consultation, and 10$25 \%$ require psychiatric treatment.

In $70-100 \%$ of people, chronic fatigue was observed. This condition very often occurs after the first dose of the preparation, it tends to increase and persist throughout the therapy. The severity of these symptoms is greater in the elderly and when higher doses of IFN are used [18]. 


\section{Hepatitis B}

Doctors recommend treatment of patients with HBsAG-positive B virus replication and elevated transaminases. Studies have shown that response to interferon treatment occurs in patients with the following characteristics:

- $\quad$ short duration of the infection

- $\quad$ high ALT activity

- $\quad$ infection in adulthood

- female

- heterosexuality

- $\quad$ HIV-minus

- HDV-minus

- $\quad$ low level of HBV-DNA in serum or low activity of HBV-DNA polymerase

- $\quad$ compensated liver disease (in liver biopsy hepititis agressiva)

As with HCV, side effects of interferon use are similar to flu symptoms: fever, chills, fatigue, myalgia, anorexia, abdominal pain, headache, nausea, vomiting and subsequently: hair loss, dizziness, difficulty attention span, bone marrow suppression, drowsiness, weight loss, diarrhea, sleep disorders, anxiety, depression, psychosis and bacterial infection [18].

\section{Genital warts}

This disease is caused by human papilloma viruses, most often type 3 and 11. Conventional pharmacotherapy and surgery are not very effective, therefore, attempts at IFN therapy have been made. Carried out by Eron et al. [5]. Clinical studies in 296 patients allowed the IFN$\alpha 2 b$ to be evaluated. The drug was used in the form of injections for lesions in an amount of 3 million units 3 times a day for 3 weeks. At the same time, a placebo trial was conducted. The first week of therapy in the placebo group did not give any results, while in the group treated with IFN- $\alpha 2$ b lesions decreased by over $60 \%$. After 3 months of observation, complete disappearance of changes was observed in $17 \%$ in the placebo group and in $36 \%$ of patients treated with recombinant IFN.

\section{Papillomatosis of the larynx}

The effectiveness of IFN- $\alpha$ has been demonstrated in the juvenile form of this disease. IFN was used in 66 children at a dose of $5 \mathrm{MU} / \mathrm{m} 2$ / day for 28 days, and then three times a week for 5 months. After this time, the control group was treated in a similar way. It was shown that both groups of patients experienced significant improvement during the use of the drug. Distant studies were analyzed after 4 years in 59 children. Complete remission was found in 24 children $(41 \%)$, while significant clinical improvement occurred in 27 children $(46 \%)$. Studies using lower doses of IFN- $\alpha$ ( 2 million IU / m2 3 times a week for a year) showed significantly worse results [19]. 


\section{Chronic hepatitis D}

Studies have shown the significant effectiveness of IFN- $\alpha$ in the treatment of hepatitis D. Therapy based on the use of this IFN at a dose of 9 million units 3 times a week results in obtaining 50\% of the total response, i.e. the disappearance of RNA-HDV from the serum and normalization of transaminases. The biochemical and virological response was accompanied by an improvement in the histopathological examination of liver biopsies. Termination of IFN- $\alpha$ therapy in some patients results in recurrence of disease symptoms, while in $20 \%$ of patients no disease recurrence was found even after 6 months from the end of cytokine therapy. In chronic hepatitis D, higher doses of IFN- $\alpha$ ( 9 MU 3 times a week) are more effective than lower doses (3 MU) [20].

\section{Hairy cell leukemia}

Natural IFN- $\alpha$ treatment gives clinical improvement in $80-100 \%$ of patients. The use of recombinant IFN- $\alpha 2 \mathrm{a}$ or IFN- $\alpha 2 \mathrm{~b}$ at a dose of 2-5 million IU / day 3 times a week results in obtaining the aforementioned percentage at a similar level. After 4-6 months from the start of the treatment, peripheral blood normalizes and the spleen decreases. Complete remission, and thus in this case complete elimination of hairy cells from the bone marrow, occurs only in 5\% of patients. In $70-80 \%$ of patients there is only partial remission, with a decrease in the percentage of leukemia cells in the bone marrow and normalization of the granulocytic, erythroid and thrombocytopenia series.

Therapeutic activity of IFN- $\alpha$ has been demonstrated in both patients undergoing previous splenectomy and in patients with preserved spleen, however spleen removal is often associated with greater specificity effectiveness.

While IFN- $\alpha$ is well tolerated, treatment can last up to 18 months, but the recommended time is one year. The average duration of remission that was achieved by IFN- $\alpha$ is 25 months. IFN$\alpha$ therapy brings the best benefits to patients with cell-rich bone marrow, a tendency to opportunistic infections, impaired immune processes, organ changes, without the associated neutropenia [21, 22].

\section{Malignant lymphomas}

IFN- $\alpha$ in combination with chemotherapy is recommended for the treatment of malignant lymphomas. Studies have shown that the addition of IFN- $\alpha$ to combined cyclic chemotherapy extends the duration of remission and the survival of patients for low- and intermediate-grade non-Hodgkin's lymphoma with an aggressive clinical course.

In T-cell cutaneous lymphomas, IFN- $\alpha$ monotherapy is moderate. Depending on the intensity of therapy and previously used chemotherapy, it is 30-45\%. Dosages reaching 50 million IU / $\mathrm{m} 2$ for 3 times a week are much more effective. The disadvantage of using such intensive therapy are unwanted symptoms. In this case, the majority of patients need to reduce the planned dose of the drug [23]. 


\section{Multiple sclerosis (MS)}

Multiple sclerosis (MS) is currently the main indication for IFN- $\beta$ (Kowalski and Białasiewicz 2000). Studies on the use of IFN- $\beta$ in medicine initiated the preliminary results of studies on the effectiveness of natural IFN- $\beta$ in advanced forms of multiple sclerosis presented by Jacobs et al. In 1981. During the study, 20 patients were given intrathecal injection at a dose of 1 million units twice a week until the 4th week, and after that time once a month for 5 months. If such therapy resulted in it, it was continued for another 18 months. Research has shown a significantly lower number of exacerbations in the IFN- $\beta$ treated group compared to the control group [24].

In other studies, where 69 patients were treated with IFN- $\beta$, also intrathecal, but at a dose of 1 million units 10 times within 6 months, similar results were obtained. Later, two-year observations showed that in patients treated with IFN- $\beta$, exacerbations occurred twice as rarely as in the placebo group [25].

As with the use of IFN- $\alpha$ drugs, IFN- $\beta$ therapy is associated with flu-like side effects. In this case, the symptoms usually occur 6-72 hours after starting treatment. Symptoms can be alleviated by administering Paracetamol. Cases have also been reported spontaneously resolving, provided the preparation is used chronically.

The dosage you take is very important because high doses of IFN- $\beta$ may show central nervous system toxicity and may cause disorientation, dizziness and depression [21, 26]. Coma, epileptic seizures, cerebral ischemia and encephalopathy have been reported in isolated cases. In addition, limb numbness and paraesthesia occur in approximately $5 \%$ of patients [27].

Other side effects are pain in lowering blood pressure and respiratory failure, acute circulatory failure and kidney failure (which is experienced less frequently). In addition, urea, bilirubin and creatinine may increase during therapy, as well as a transient increase in serum alkaline phosphatase and transaminases. Moderate proteinuria has been reported in isolated cases. IFN- $\beta$ by its myelosuppressive effects may cause thrombocytopenia, leukoponies and anemia, however, the severity of these symptoms is so weak that it rarely results in dose reduction or complete discontinuation of therapy.

Despite so many side effects, it should be noted that these symptoms are usually low and occur relatively rarely. Patients are forced to reduce the dose or stop treatment only in $10 \%$ of cases [20, 28, 29].

\section{Chronic granulomatous diseases}

IFN- $\gamma$ tolerance is generally good. In patients treated for PCZ at a dose of $50 \mu \mathrm{m} / \mathrm{m} 2$ every 2 days, the most common side effects were headache, chills, fever and skin erythema at the injection site. These symptoms affected $10-50 \%$ of patients, but resolved after using aceminofen (paracetamol). Side effects in patients over the age of 10 were twice as common as in younger children. Some patients complained about anorexia, muscle and joint pain, fatigue, nausea, vomiting, diarrhea and skin rash. Dose reduction or discontinuation were not a frequent consequence of adverse reactions.

Patients who received higher doses of IFN- $\gamma$ showed side effects similar to those in patients who used this specific product at lower doses due to chronic granulomatous disease. Individual patients have experienced cardiovascular disorders in the form of hypotonia, 
arrhythmias, syncope, myocardial infarction and heart failure symptoms, pancreatitis, reversible acute liver and kidney failure, and gastrointestinal bleeding.

Rarely, adverse reactions were transient toxic effects on the nervous system in the form of Parkinson's, disorientation, confusion, cerebral ischemia and hallucinations. Cases of deep vein thrombosis, pulmonary embolism, bronchospasm, faster breathing, hyperglycemia and hyponatraemia have also been reported [30, 31].

\section{Treatment of infectious diseases}

The immunostimulatory and immunomodulatory properties of IFN- $\gamma$ have prompted scientists to undertake clinical trials on its possible application in the therapy of bacterial, viral and fungal diseases, especially in immunocompromised patients.

Studies in AIDS patients with co-existing, life-threatening infections and Kaposi's sarcoma have shown an increase in MHC class II antigen expression and an increase in monoxide hydrogen peroxide production. The biochemical changes were accompanied by the growth of macrophages to destroy extracellular and intracellular germs. Among the results there was no confirmation whether IFN- $\gamma$ had a clear effect on the process of opportunistic infections or on the regression of Kaposi's sarcoma [32].

In vitro studies have shown the inhibitory effect of IFN- $\gamma$ on the proliferation of Epstein-Barr virus (EBV) and the simultaneous prevention of tumor transformation caused by it. This case was noted by Okano et al. [33] in a study in which a 20-month-old boy with infectious mononucleosis and familial lymphoproliferative syndrome associated with the $\mathrm{X}$ chromosome was treated with IFN- $\gamma$. Rapid clinical improvement and a significant reduction in the number of cells infected with the virus in the blood were noted after using this drug.

The rightness of IFN- $\gamma$ in selected cases of chronic EBV infection was demonstrated by Fujisaki et al. [34] in their studies. The patient was a 27-year-old male infected with this virus with symptoms of generalized lymphadenopathy, pancytopenia, fever, hepatosplenomegaly and pneumonia. After a dose of 3x106 U / day for 2 weeks, rapid clinical relief was achieved. In the case of parasitic diseases, it is suspected that IFN- $\gamma$ can be used as a medicine, especially for leishmaniasis. When combined with pentamidine, IFN- $\gamma$, it gives much better results than other treatments. A definite clinical improvement is achieved in $75 \%$ of patients treated in this way, despite previous resistance to pentamidine monotherapy [32].

\section{Kidney cancer}

Two cytokines - IL-2 and IFN- $\alpha$ have been used in the treatment of selected patients with metastatic kidney cancer. In Europe, primarily IFN- $\alpha$ is used. Among patients with kidney cancer, $15 \%$ of them respond to IFN- $\alpha$ therapy. Often better results are obtained with high doses of IFN- $\alpha$ (20-50 million IU / day). The high toxicity of such high doses means that the recommended doses do not exceed 5 million IU / day. Response to treatment is usually achieved after 1-3 months. The average time of remission is usually about 6 months and only about 35\% of patients exceed one year [35]. Studies by the Southwest Oncology Group (SWOG) and the European Organization for Research and Treatment of Cancer (EORTC) have shown that the success of treatment depends on the nephrectomy. In the 2004 studies, the patients participating in them were randomly divided into two groups - patients treated 
only with IFN- $\alpha$ and IFN- $\alpha$ preceded by nephrectomy. The overall survival time of patients in the second group was significantly longer (13.6 and 7.8 months, respectively) [36].

\section{Chronic myeloid leukemia}

The exact mechanism of action of IFN- $\alpha$ in chronic myelogenous leukemia has not been fully understood. One of the theses is that it causes changes in the bone marrow microenvironment, enhancing the adhesion of leukemia cells to bedding and interferes with the local production of cytokines that stimulate the anti-cancer cell response. The first publication regarding the use of IFN- $\alpha$ in the chronic phase of chronic myelogenous leukemia appeared in the early 1980s. It has been proven that in most patients IFN- $\alpha$ results in complete hematological remission, and in some of them to partial or complete cytogenetic remission. Later studies, consisting of comparing the effectiveness of IFN- $\alpha$ therapy with conventional chemotherapy, showed an increase in patients' survival by about 2 years using cytokine therapy. IFN- $\alpha$ therapy includes patients with $\mathrm{PBSz} \mathrm{PH}(+)$ who are not eligible for hematopoietic cell allotransplantation (low risk patients who do not have bone marrow donors). IFN- $\alpha$ therapy can cause side effects. The most serious include immunosuppression, which often imposes the need to reduce or even temporarily stop the drug. Other side effects include supposedly flu symptoms, and after prolonged therapy weight loss, depression, alopecia, fatigue, insomnia and even bone marrow hypoplasia. Rare cases of autoimmune complications have been reported, including thrombocytopenia, haemolytic anemia, vasculitis, hypothyroidism, and nephrotic syndrome. Elderly patients over 60-70 years of age particularly do not tolerate IFN$\alpha$ therapy. Many attempts have been made to modify the IFN- $\alpha$ molecule to reduce side effects. The combination of IFN with polyethylene glycol has been proven to improve the properties of the drug molecule, namely, prolongs the absorption period and reduces adverse effects [37].

In the chronic phase of myelogenous leukemia, therapy with recombinant IFN- $\gamma$ at a dose of $0.25-, 0.5 \mathrm{mg} / \mathrm{m} 2$ does not lead to cytogenetic remission, whereas haematological remission is only achieved in approximately $25 \%$ of patients. Despite the synergism of IFN- $\gamma$ and IFN- $\alpha$ in preclinical studies, the combination of these two cytokines is not more effective than IFN- $\alpha$ monotherapy.

Studies have been conducted on the use of IFN- $\gamma$ in the treatment of acute myeloid leukemia. The patients were 14 children with acute myeloid leukemia during relapse. The first phase of clinical trials was to give patients a dose of 0.1-0.75 mg / m2 (1.0-7.5 x $106 \mathrm{U} / \mathrm{m} 2)$. Research has shown stabilization or partial regression of leukemia in three children, while one child has experienced transient acute renal failure. The preparation was generally well tolerated. In the second phase of clinical trials, the recommended dose of IFN- $\gamma$ was $0.5 \mathrm{mg} /$ $\mathrm{m} 2$ / day [38, 39]. 


\section{COVID19 (SARS-CoV-2)}

SARS-CoV-2 is the seventh known coronavirus that infects humans, which, together with SARS-CoV, MERS-CoV, can cause serious illness. HKU1, NL63, OC43 and 229E variants usually cause mild disease symptoms [40]. The attention of scientists from around the world focused on the SARS-CoV-2 study after the outbreak of the pandemic that began in 2019 in Chinese Wuhan. According to the situation report published by the World Health Organization (WHO) as of June 22, 2020, 8860331 cases and 465740 deaths were confirmed worldwide [41]. SARS-CoV2 causes a lower respiratory tract infection that results in pneumonia in humans. Although the symptoms are milder than those of SARS-CoV and MERS-CoV, excessive inflammation and breathing disorders can cause acute respiratory distress syndrome (ARDS) and multi-organ failure (MODS), resulting in death in a short period of time. One of the main causes of ARDS and MODS is the cytokine storm [42, 43].

Clinical studies have detected the presence of a cytokine storm in critical SARS-CoV-2 patients [44]. Its suppression may prove to be an effective way to stop the deterioration of health of COVID-19 patients [45]. Despite the differences in pathology, epidemiology and the presence of proteins, MERS-CoV and SARS-CoV exhibit similar properties and are closely related to SARS-CoV-2. About 75 percent of the SARS-CoV2 genome is identical to the SARS-CoV genome [43]. Numerous studies are available, both in vitro and in vivo, in which IFN-I was used to treat MERS-CoV and SARS-CoV [46, 47]. Although IFN $\alpha$ and $\beta$ were effective in in vitro studies in animal models [48], they did not show significant improvement in humans [46]. The combination of IFN $\beta$ with lopinavir / ritonavir used against MERS-CoV, despite improved lung function, did not significantly reduce the severity of lung pathology or viral replication [49]. In turn, the combination of IFN $\alpha 2 b$ with ribavirin gave excellent results in Macaca mulatta [50] but no unequivocal result in humans [51]. The explanation for the lack of significant improvement in the patient's health during IFN-I treatment may be the mechanisms of inhibition of the IFN signaling pathway demonstrated in MERS-CoV and SARS-CoV or a limited number of experimental animals or patients. Chinese multicenter studies have shown that administration within 7 days of symptoms of a triple combination of injection interferon (IFN $\beta 1 b$ ), an oral protease inhibitor (lopinavir-ritonavir) and an oral nucleoside analogue (ribavirin) effectively inhibits SARS-CoV-2 secretion in both nasopharyngeal swabs, as well as in all clinical samples. In addition, after 8 days of therapy patients had negative RT-PCR results. Side effects in most cases were mild and self-limiting [52]. Using IFN with other medications makes it difficult to assess which compound has caused a possible improvement in health. Al-Tawfiq et al. [53] and Shalhoub et al. [54]suggested that IFN's ineffectiveness is due to comorbidities. It has been shown that SARS-CoV and MERS-CoV have Orf6 and Orf3b proteins that can interfere with the interferon signaling pathway $[55,56]$. These proteins in SARS-CoV-2 are truncated and have probably lost their anti-interferon functions. This fact may explain the significant sensitivity of SARS-CoV-2 to IFN $\alpha$ manifested in the incomplete suppression of SARS-CoV-2 replication by interferons, while reducing the viral load by several orders of magnitude [57]. IFNa2b sprays have been shown to reduce the SARS-CoV-2 infection rate [58]. It provides the basis for the statement that IFN-I can be used in the prophylaxis against SARS-CoV-2. Efficacy has been confirmed in vitro [57]. Interestingly, IFN-I does not affect MERS-CoV and SARS-CoV replication [59, 60]. COVID-19 pathology consists primarily of pulmonary 
lesions and resembles interferonopathy. This may suggest that SARS-CoV-2 induces an excessive IFN-I mediated antiviral response, leading to tissue damage. If this hypothesis is confirmed, IFN-I treatment should be limited to the early stages of infection. In the late phases, it is even possible to use anti-interferon drugs to alleviate pathology [61]. Chinese guidelines for the treatment of COVID-19 assume the administration of 5 million IFN $\alpha$ units in combination with ribavirin twice a day by steam inhalation [62,63]. The advantage of using vapor inhalation is that it specifically targets the respiratory tract. The use of ribavirin improves the effectiveness of IFN-I, which has been documented in in vitro studies in other coronaviruses [49].

\section{SUMMARY}

Thanks to their properties interferons have been widely used in the treatment of both viral and cancer diseases for many years. Currently, they constitute an important element in the search for a drug against SARS-CoV-2, which, because of its global reach, poses a threat not only in medical but also in socio-economic and social terms.

\section{REFERENCES}

1. Isaacs A, Lindenmann J. Virus interference. I. The interferon. J. Interferon Res. 1987;7:429-38.

2. Obołończyk Ł, Siekierska-Hellmann M, Sworczak K. Powikłania leczenia interferonem alfa wirusowego zapalenia wątroby typu C ze szczególnym uwzględnieniem zaburzeń funkcji tarczycy. Postepy Hig. Med. Dosw. 2008;62:309-21.

3. Berkman A, Kaczorowski S, Bakalar N. Wirusowe zapalenie wątroby: typy od A do $\mathrm{G}$ : występowanie, zapobieganie, leczenie. Klub dla Ciebie. 2006.

4. Rusiecka-Ziółkowska J, Fleischer M, Staroszczyk J. Właściwości immunologiczne Gram-ujemnych pałeczek Pseudomonas aeruginosa Immunological properties of the Gramnegative bacilli Pseudomonas aeruginosa Word count. 2007:61.

5. Eron LJ, Judson F, Tucker S, Prawer S, Mills J, Murphy K et al. Interferon therapy for condylomata acuminata. N Engl J Med. 1986;315:1059-64.

6. Alfred Zejc, Gorczyca M. Współczesne metody projektowania i otrzymywania leków. trzecie. Warszawa: Wydawnictwo Lekarskie PZWL. 2013.

7. Głobińska A, Kowalski ML. Interferon alfa: Perspektywy zastosowania w leczeniu wirusowych zakażeń dróg oddechowych. Alerg. Astma Immunol. 2013;18:97-103.

8. Domagalski K, Tretyn A, Pawłowska M, Szczepanek J, Halota W. Action of type III IFNs and their roles in immune responses. Postepy Hig. Med. Dosw. 2010;64:522-33.

9. Buczko W. Farmakologia i toksykologia. 2012.

10. Jakóbisiak M. Immunologia. 2000.

11. Tencate V, Sainz B, Cotler SJ, Uprichard SL. Potential treatment options and future research to increase hepatitis $\mathrm{C}$ virus treatment response rate. Hepatic Med. Evid. Res. 2010;2:125-45.

12. Powell DW, Abramson BZ, Balint JA, Belle S, Bloomer JR, Diehl AK et al. National Institutes of Health Consensus Development Conference Panel statement: management of hepatitis C. Hepatology. 1997;26:2S-10S.

13. Tine' F, Magrin S, Craxi' A, Pagliaro L. Interferon for non-A, non-B chronic hepatitis. 
A meta-analysis of randomised clinical trials. J. Hepatol. 1991;13:192-9.

14. Thévenot T, Regimbeau C, Ratziu V, Leroy V, Opolon P, Poynard T. Meta-analysis of interferon randomized trials in the treatment of viral hepatitis $C$ in naive patients: 1999 Update. J. Viral Hepat. 2008;8:48-62.

15. Brillanti S, Garson J, Foli M, Whitby K, Deaville R, Masci C et al. A pilot study of combination therapy with ribavirin plus interferon alfa for interferon alfa-resistant chronic hepatitis C. Gastroenterology. 1994;107:812-7.

16. Pawłowski T. Rola szlaku kinureninowego w patogenezie objawów zespołu depresyjnego u pacjentów z przewlekłym wirusowym zapaleniem wątroby typu C leczonych pegylowanym interferonem alfa 2a i rybawiryną. 2011.

17. Jakóbisiak M. Immunologia. 1995.

18. Juszczyk J. Leczenie chorób wirusowych. 2000.

19. Carpenter G, Cohen S. Epidermal Growth Factor. Annu. Rev. Biochem. 1979;48:193216.

20. Guidi AJ, Abu-Jawdeh G, Tognazzi K, Dvorak HF, Brown LF. Expression of vascular permeability factor (vascular endothelial growth factor) and its receptors in endometrial carcinoma. Cancer. 1996;78:454-60.

21. Bruijn JA, Roos A, de Geus B, de Heer E. Transforming growth factor-beta and the glomerular extracellular matrix in renal pathology. J. Lab. Clin. Med. 1994;123:34-47.

22. Han ZC, Sensebe L, Abgrall JF, Briere J. Platelet factor 4 inhibits human megakaryocytopoiesis in vitro. Blood. 1990;75:1234-9.

23. Hoffman R. Regulation of Megakaryocytopoiesis. Blood. 1989;74:1196-212.

24. Jacobs L, O’Malley J, Freeman A, Ekes R. Intrathecal interferon reduces exacerbations of multiple sclerosis. Science (80-. ). 1981;214:1026-8.

25. Erickson-Miller CL, Parchment RE, Zhang ZG, Ji H, Dai W, Murphy MJ et al. Purification of human megakaryocyte colony-stimulating factor (Meg-CSF) from urine of aplastic anemia patients. Int. J. Cell Cloning. 1991;9:204-21.

26. Hart CE, Bailey M, Curtis DA, Osborn S, Raines E, Ross R et al. Purification of PDGF-AB and PDGF-BB from Human Platelet Extracts and Identification of All Three PDGF Dimers in Human Platelets. Biochemistry. 1990;29:166-72.

27. Gospodarowicz D. Fibroblast growth factor. Crit. Rev. Oncog. 1989;1:1-26.

28. Clemmons DR, Van Wyk JJ. Factors controlling blood concentration of somatomedin C. Clin. Endocrinol. Metab. 1984;13:113-43.

29. Gleave ME, Hsieh JT, Wu HC, Hong SJ, Zhau HE, Guthrie PD et al. Epidermal Growth Factor Receptor-mediated Autocrine and Paracrine Stimulation of Human Transitional Cell Carcinoma. Cancer Res. 1993;53:5300-7.

30. Fisher DA, Lakshmanan J. Metabolism and effects of epidermal growth factor and related growth factors in mammals. Endocr. Rev. 1990;11:418-42.

31. Graham GJ, Pragnell IB. SCI MIP-1 $\alpha$ : A potent stem cell inhibitor with potential roles in development. Dev. Biol. 1992;151:377-81.

32. Anderson DJ. New roles for PDGF and CNTF in controlling the timing of glial cell differentiation in the optic nerve. Trends Neurosci. 1989;12:83-5.

33. Okano M, Thiele GM, Gross TG, Davis JR, Purtilo DT. Differential cellular susceptibility to Epstein-Barr virus infection in a patient with X-linked lymphoproliferative 
disease. J. Med. Virol. 1990;32:47-52.

34. Fujisaki T. Gamma-Interferon for Severe Chronic Active Epstein-Barr Virus. Ann. Intern. Med. 1993;118:474.

35. Łucka M, Kowalczyk T, Szemraj J, T. S. Rośliny jako alternatywne źródła białek terapeutycznych. Postepy Hig. Med. Dosw. 2015;69:362-73.

36. Drosik A, Drosik K. Leczenie chorych na przerzutowego raka nerkowokomórkowego — fakty czy logika poparta faktami ? 2010:311-7.

37. Seferyńska I, Warzocha K. Postęp w leczeniu przewlekłej białaczki szpikowej. Onkol. w Prakt. Klin. 2005;1:40-8.

38. Derynck R, Goeddel D V., Ullrich A, Bringman TS, Berger WH, Gutterman JU et al. Synthesis of Messenger RNAs for Transforming Growth Factors $\alpha$ and $\beta$ and the Epidermal Growth Factor Receptor by Human Tumors. Cancer Res. 1987;47:707-12.

39. Erickson-Miller CL, Ji H, Parchment RE, Murphy MJ. Megakaryocyte colonystimulating factor (Meg-CSF) is a unique cytokine specific for the megakaryocyte lineage. $\mathrm{Br}$. J. Haematol. 1993;84:197-203.

40. Andersen KG, Rambaut A, Lipkin WI, Holmes EC, Garry RF. The proximal origin of SARS-CoV-2. Nat. Med. 2020;26:450-2.

41. World Health Organization. Situation updates on June 22, 2020. .

42. Ye Q, Wang B, Mao J. The pathogenesis and treatment of the 'Cytokine Storm'' in COVID-19.' J. Infect. 2020;80:607-13.

43. Nile SH, Nile A, Qiu J, Li L, Jia X, Kai G. COVID-19: Pathogenesis, cytokine storm and therapeutic potential of interferons. Cytokine Growth Factor Rev. 2020. doi:10.1016/j.cytogfr.2020.05.002.

44. Wan S, Yi Q, Fan S, Lv J, Zhang X, Guo L et al. Characteristics of lymphocyte subsets and cytokines in peripheral blood of 123 hospitalized patients with 2019 novel coronavirus pneumonia (NCP). medRxiv. 2020:2020.02.10.20021832.

45. Ye Q, Wang B, Mao J. The pathogenesis and treatment of the 'Cytokine Storm', in COVID-19.' J. Infect. 2020;80:607-13.

46. Stockman LJ, Bellamy R, Garner P. SARS: Systematic Review of Treatment Effects. PLoS Med. 2006;3:e343.

47. Sallard E, Lescure FX, Yazdanpanah Y, Mentre F, Peiffer-Smadja N. Type 1 interferons as a potential treatment against COVID-19. Antiviral Res. 2020. doi:10.1016/j.antiviral.2020.104791.

48. Fuk-Woo Chan J, Yao Y, Yeung M-L, Deng W, Bao L, Jia L et al. Treatment With Lopinavir/Ritonavir or Interferon- $\beta 1 \mathrm{~b}$ Improves Outcome of MERS-CoV Infection in a Nonhuman Primate Model of Common Marmoset. 2015. doi:10.1093/infdis/jiv392.

49. Sheahan TP, Sims AC, Leist SR, Schäfer A, Won J, Brown AJ et al. Comparative therapeutic efficacy of remdesivir and combination lopinavir, ritonavir, and interferon beta against MERS-CoV. Nat. Commun. 2020;11:1-14.

50. Falzarano D, De Wit E, Martellaro C, Callison J, Munster VJ, Feldmann H. Inhibition of novel $\beta$ coronavirus replication by a combination of interferon- $\alpha 2 b$ and ribavirin. Sci. Rep. 2013;3:1-6.

51. Arabi YM, Shalhoub S, Al-Omari A, Mandourah Y, Al-Hameed F, Sindi A et al. Effect of ribavirin and interferon on the outcome of critically ill patients with MERS. Am. J. 
Respir. Crit. Care Med. 2017.

52. Hung IFN, Lung KC, Tso EYK, Liu R, Chung TWH, Chu MY et al. Triple combination of interferon beta-1b, lopinavir-ritonavir, and ribavirin in the treatment of patients admitted to hospital with COVID-19: an open-label, randomised, phase 2 trial. Lancet. 2020;395:1695-704.

53. Al-Tawfiq JA, Momattin H, Dib J, Memish ZA. Ribavirin and interferon therapy in patients infected with the Middle East respiratory syndrome coronavirus: An observational study. Int. J. Infect. Dis. 2014;20:42-6.

54. Shalhoub S, Farahat F, Al-Jiffri A, Simhairi R, Shamma O, Siddiqi N et al. IFN- $\alpha 2 a$ or IFN- $\beta 1 \mathrm{a}$ in combination with ribavirin to treat Middle East respiratory syndrome coronavirus pneumonia: A retrospective study. J. Antimicrob. Chemother. 2015;70:2129-32.

55. Frieman M, Yount B, Heise M, Kopecky-Bromberg SA, Palese P, Baric RS. Severe Acute Respiratory Syndrome Coronavirus ORF6 Antagonizes STAT1 Function by Sequestering Nuclear Import Factors on the Rough Endoplasmic Reticulum/Golgi Membrane. J. Virol. 2007;81:9812-24.

56. Kopecky-Bromberg SA, Martínez-Sobrido L, Frieman M, Baric RA, Palese P. Severe Acute Respiratory Syndrome Coronavirus Open Reading Frame (ORF) 3b, ORF 6, and Nucleocapsid Proteins Function as Interferon Antagonists. J. Virol. 2007;81:548-57.

57. Lokugamage KG, Hage A, Schindewolf C, Rajsbaum R, Menachery VD. SARS-CoV2 is sensitive to type I interferon pretreatment. Cold Spring Harbor Laboratory. 2020;21:1-9. 58. Shen KL, Yang YH. Diagnosis and treatment of 2019 novel coronavirus infection in children: a pressing issue. World J. Pediatr. 2020:1-3.

59. Thiel V, Weber F. Interferon and cytokine responses to SARS-coronavirus infection. Cytokine Growth Factor Rev. 2008;19:121-32.

60. Menachery VD, Yount BL, Josset L, Gralinski LE, Scobey T, Agnihothram S et al. Attenuation and Restoration of Severe Acute Respiratory Syndrome Coronavirus Mutant Lacking 2'-O-Methyltransferase Activity. J. Virol. 2014;88:4251-64.

61. Zhang W, Zhao Y, Zhang F, Wang Q, Li T, Liu Z et al. The use of anti-inflammatory drugs in the treatment of people with severe coronavirus disease 2019 (COVID-19): The experience of clinical immunologists from China. Clin. Immunol. 2020;214:108393.

62. Dong L, Hu S, Gao J. Discovering drugs to treat coronavirus disease 2019 (COVID19). Drug Discov. Ther. 2020;14:58-60.

63. Lu H. Drug treatment options for the 2019-new coronavirus (2019-nCoV). Biosci. Trends. 2020;14:69-71. 